\title{
Lithostratigraphy of the Late Cretaceous Khao Ya Puk Formation in Nakhon Thai Region, Thailand: Implication for Depositional Environment
}

\author{
Pradit Nulay $^{1 *}$, Parinthon Intharajak ${ }^{2}$ \\ ${ }^{1}$ Office of Mineral Resources Region 2, Department of Mineral Resources, Ministry of Natural Resources and Environment, Khon \\ Kaen, Thailand \\ ${ }^{2}$ Department of Geotechnology, Faculty of Technology, Khon Kaen University, Khon Kaen, Thailand \\ Email: *Pradit_2004@yahoo.com
}

How to cite this paper: Nulay, P. and Intharajak, P. (2019) Lithostratigraphy of the Late Cretaceous Khao Ya Puk Formation in Nakhon Thai Region, Thailand: Implication for Depositional Environment. Open Journal of Geology, 9, 711-713. https://doi.org/10.4236/ojg.2019.910082

Received: August 17, 2019

Accepted: September 22, 2019

Published: September 25, 2019

Copyright () 2019 by author(s) and Scientific Research Publishing Inc. This work is licensed under the Creative Commons Attribution International License (CC BY 4.0).

http://creativecommons.org/licenses/by/4.0/

\begin{abstract}
The Khao Ya Puk Formation ( $>400 \mathrm{~m}$ thick) is well exposed in the Nakhon Thai Region, and is subdivided into three members. The Khao Ya Puk Formation overlies conformably on top of the anhydrite layer of the upper rock salt Maha Sarakham Formation. In turn, it is overlain unconformably by the Phu Khat Formation. The Khao Ya Puk Formation is interpreted to have been deposited by freshwater lake area in arid climate inland subkha in the Late Cretaceous. Lithostatigraphically, Khao Ya Puk Formation can be correlated with the Phu Tok Formation that has been deposited in the Khorat-Ubon basin and Udon-Sakon basin of the Khorat Plateau.
\end{abstract}

\section{Keywords}

Khao Ya Puk Formation, Nakhon Thai Region, Lithostratigraphy

\section{Introduction}

The stratigraphy of the non-marine Khorat Group in the Khorat Plateau has long been studied by many geoscientists. The sequence of the Khorat Group extends beyond the rim of Khorat Plateau to the Nakhon Thai region [1]. The two regions are separated by pre-Cretaceous rocks in the Loei-Phetchabun Fold Belt. The stratigraphy of the upper most part of the red beds is mentioned in Nakhon Thai region, namely, as the Khao Ya Puk Formation. Nonetheless, the detailed lithostratigraphy of the formation is still ambiguous. Therefore, the main objec- 
tive of this study is focusing on its lithostratigraphy according to three reference sections.

\section{Stratigraphy}

\subsection{Definition and Type Section}

The Khao Ya Puk Formation was named by Kosuwan [2] in geological map in scale of 1:50,000 on Thai Royal Survey Department topographic map series L7018 sheet 5143 I \& II of Ban Nam Khum and Amphoe Nakhon Thai. The formation thickness is 200-350 meters. The designated type section is broadly located on a local road from $\mathrm{Na}$ Khon Thai to Ban Nam Khum, but the detailed lithology was not described. In this study, three reference localities are designated and measured including Khao Kadai Ma temple section, Route No_2195 Na Haeo District-Ban Pak Man section, and Route No_2113 Dan Sai District-Ban Nongsim section.

\subsection{Contact}

Lower contact: A ground water drill well at Ban Nam Lat, NaKhon Thai District, has proved that the Khao Ya Puk Formation is underlain conformably by the Maha Sarakham Formation [3].

Upper contact: The Khao Ya Puk Formation is overlain unconformably by the Phu Khat Formation [4]. The abrupt facies change between the two formations together with the contrasting detrital zircon age support the interpretation.

\subsection{Lithology and Extend}

The lower Khao Ya Puk Member is composed of thick bedded reddish brown mudstone, yielding obvious calcrete nodules in the upper part. The middle Khao Ya Puk Member consists of reddish brown sandstone interbedded with shale and siltstone. Giant mud cracks and calcrete nodules occurred in shale beds. Sandstone moderate- to very fine-grained, well sorted, sub rounded to well rounded with cross bedding, sole marks, and mud drape are present. The upper Khao Ya Puk Member is characterized by thick bedded reddish brown sandstone. It is moderate- to fine-grained, well sorted and well rounded with a large cross-bedding and high angle foresets.

The Khao Ya Puk Formation is presented throughout the area of this paper and extends somewhat northeast to north into Uttaradit province and beyond the Thailand border into the Ken Thao area in Laos. In the study area, the formation exposes in Chat Trakan and Nakhon Thai district of Phitsanulok province and Na Haeo and Dan Sai district of Loei province. The thickness throughout the formation is not less than 400 meters.

\subsection{Age and Correlation}

As the formation is underlain conformably by the mid-Cetaceous rock salt Maha Sarakham Formation [5] and covered by the latest Cetaceous Phu Khat Formation [4], therefore the formation is assigned to the Late Cretaceous. Lithostati- 
graphically, the Khao Ya Puk Formation can be correlated with the Phu Tok Formation. The rock sequence contains in both formations which have similar lithology showing a coarsening and thickening upward sequence.

\subsection{Depositional Environment}

The Khao Ya Puk Formation is interpreted to have been deposited by freshwater lake area in arid climate inland subkha in the Late Cretaceous. The lower member is interpreted to be deposited at center of the lake as it is characterized by the thick bedded reddish brown mudstone. The middle member is marginal of the lake as it presents the reddish brown sandstone interbedded with shale and siltstone with the giant mud crack. The upper member is interpreted to be of an aeolian dune and inter-dune environment of the last stage of deposition as it is characterized by well sorted and well rounded sandstone with large scale cross-bedding and high angle foresets with an inverse grade.

\section{Conclusion}

The $400 \mathrm{~m}$ thick Khao Ya Puk Formation can be subdivided into three members. It can be correlated with the Phu Tok Formation in the Khorat Plateau, conformably overlies the Maha Sarakham Formation, and is overlain unconformably by the Phu Khat Formation. It was deposited by freshwater lake area in arid climate inland subkha in the Late Cretaceous.

\section{Acknowledgements}

This work is a contribution to UNESCO/IUGS/IGCP 679 project.

\section{Conflicts of Interest}

The authors declare no conflicts of interest regarding the publication of this paper.

\section{References}

[1] Sha, J.G., Meesook, A. and Nguyen, X.K. (2012) Non Marine Cretaceous Bivalve Biostratigraphy of Thailand, Southern Lao PDR and Central Vietnam. Journal of Stratigraphy, 36, 382-399.

[2] Kosuwan, S. (1990) Geology of Nakhon Thai District and Ban Nam Kum; in Scale 1:50000. Bangkok, Thailand. Department of Mineral Resources. (in Thai)

[3] Meesook, A. (2011) Cretaceous. In: Ridd, M.F., Barber, A.J. and Crow, M.J., Eds., The Geology of Thailand, The Geological Society of London, United Kingdom.

[4] Nulay, P. (2014) Facies Characteristic of the Late Cretaceous-Paleogene Sediments (Phu Khat Formation) in the Nakhon Thai Region: Implications for Tectonic Evolution. Dissertation, Suranaree University of Technology, Nakhon Ratchasima.

[5] Hansen, B.T., Wemmer, K., Pawlig, S., Klaus, J., Assavapatchara, S., Nontaso, M. and Putthapiban, P. (2002) Isotopic Evidence for a Late Cretaceous Age of the Potash and Rock Salt Deposit at Bamnet Narong, NE Thailand. In: The Symposium on Geology of Thailand, 26-31. 